\title{
The research about Internet financial development under "the Belt and Road" strategy in China
}

\author{
Qing Ge \\ International Business School \\ Yunnan University of Finance and Economics \\ Kunming, China \\ 385604122@qq.com
}

\begin{abstract}
Nowadays, within the development of modern electronic information technologies, Internet Finance flourishes and changes with each passing day. It becomes an vital sector of modern finance for changing the conducting financial activities and leading a new trend.The born and wide use of Internet Finance enhances the efficiency of financial services and shortens the distance between financial industry and public. This paper analyzing the development and characteristics of Internet Finance in China and abroad, the impact and trends for its further developing, suggestions how to prevent potential risks and supervision should be improved according to successful Internet Finance experiences abroad..
\end{abstract}

Keywords-Internet Finance; Risk control; Financial supervision

\section{INTRODUCTION}

The Belt and Road initiative advocates to build an allround,multilevel and stereo relationship, finance plays a vital and essential role and occupies the basic position. Under this special background, Internet Finance springs up exuberantly and expands rapidly. Therefore, 2013 was called the year of Internet Finance and a year with an epoch-making reform according to some financial economists. However, highly attention has been payed these years, there is a great deal of arguments about the concept of Internet Finance, methods of supervision, risk evaluation, impact assessment and developing trends need to be discussed. This paper reviews the development and characteristics of Internet Finance in China and abroad, analyzes the financial impact and trends for further developing, provides suggestions to regulate the development, protect the rights of financial participants and stabilize the financial system according to the successful Internet Finance experiences overseas such as how to prevent potential risks and improve government's supervision.

\section{THE DEVELOPMENT OF INTERNET FINANCE IN CHINA}

Internet Finance in China takes shape with a rapid speed even has a rather late start. 2013 is called the Internet Finance year in China. In 2013, third-party payment emerged and widespread, such as Alipay, Tenpay and QuickPay. Besides, Yu’ebao, generated from Alipay, expanded from $¥ 0.2$ billion to 185.3 billion and attract $6 \%$ market share in Chinese financial fund in half a year. P2P internet lending platform were established and provided loans to SME and individual customers like Ali loans, Renren loans and CreditEase. In Traditional Finance, it's hard to get loans for SME and individuals for its large demand but lower credit. P2P lending platform help to release the pressure of capital turnover in a short time. Thus, Internet Finance incurred huge crash to the Traditional Finance.

There are four types of Internet Finance models and every type has a analysis as following:

\section{A. The third-party Payment}

Internet payment makes use of internet payment channel to transfer money from borrowers to lenders. At the same time, it is more convenient even transaction occurred cross banks and regions and much safer for the capital. As the data showed, there are more than 250 third payment licenses have been issued until the end of 2013. Among this 250 licenses, 150 are distributed to Prepaid card companies and 97 are belong to companies who are operating internet payment service, such as Alipay and Tenpay. And there are $¥ 15.338$ billion transactions completed and amount of money in total up to $¥$ 9.22 trillion.

\section{B. Internet Financial Service}

Cooperating of financial institutions and E-commerce come up with internet financial service. In general, financial institutions responsible for the designing and operating financial products. However, E-commerce has a large number of customers. For customers, they can check their financial benefits anytime anywhere via internet. Usually, these financial products are combined with well social reputation as a guarantee and supportive technologies. It also can lessen the hazard caused by information asymmetry.

The most successful internet service tools should be Yu'ebao and WeChat Finance. These kinds of internet financial tools connect the payment platform and Monetary fund, and featured with a low base, short term, high benefit, flexible model and service fee waived. The amount of money for Yu’ ebao was up to $¥ 0.4$ trillion and number of users were up to 61 million until February, 2014.

\section{Internet Fund Investing and Raising}

The channel of internet fund investing and raising is a platform build by borrowers lenders, and shifts the transaction from traditional financial and private lending to online form. 
This kind of model was aiming at reducing transaction cost, sharing risk, overcoming region restrictions, overcoming size restrictions and improving the efficiency of cash flow. According to iResearch Report, there are three dimensions of domestic internet fund investing and raising. They are P2P Lending, Supply Chain Financial Services and Crowd-funding. A deep analysis is showing as follows:

The most representative company of $\mathrm{P} 2 \mathrm{P}$ Lending is CreditEase, Renren Cerdit and Paipai Credit.According to the statistics. There are over 132 P2P Enterprises enrolled until the first quarter of 2013.

Ali credit and Jing'baobei can represent Supply Chain Financial Services. The loan launching were up to $¥ 0.2$ trillion and over 800 thousand SME get money form Ali Credit. Most important of all, even the speed of lending is rapid, the nonperforming loans ratio was still under $1 \%$. It can show the abilities of well risk allocation and regulation.

Outstanding enterprises of Crowd-funding are Dianmingshijian, Dreamore Website and Angel Crunch. For instance, the dianmingshijian gained about 5500 programs only setting up for a year in the first half year of 2012. In these 5500 programs, 318 had passed, 150 reached the standard, and the ratio of success is $47 \%$. In total, it received $¥ 3$ million and the highest crowd-funding for a program was up to $¥ 340$ thousand. However, Crowd-funding is still got a lower recognition, investors invest the program for the idea. It's not a borrower-lender relationship but a grant. For the investor, Return On Investment was mainly comes from the program itself not the benefit.

\section{Bit-coin}

As this paper mentioned before, there are different perspectives of Bit-coin in US, France and Germany. Now the development of Bit-coin in China can be analyzed and summarized as follows. The speculative demand of Bit-coin was infinite zoomed for weakness of internet technology and supervision. The Bit-coin was inflated by a large number of investors and price was rampant in one period. Its high risk was exposed but hardly predictable and solved. Therefore, the central bank called off it in its rapid moment and regulations promulgated one after another. That means Bit-coin has no market in China for a further long term. In short, it's very dramatic for the development of Bit-coin in China. It is rigorous as flower, and fleeting as fireworks. Nonetheless, it doesn't mean Bit-coin expel forever. The most important thing is a well-invest land should be build to avoid speculation. Then Bit-coin and other virtual monetary can be introduced again in the future.

It is easy to find the development speed of domestic Internet Finance far exceeded developed countries. The reasons are as following. Firstly, financial institutions are not rely on the free market but on the domestic financial monopoly. Thus, under the support and protect, it is hard to be sensitive to the survival in a free market. Therefore, even with a lower operating efficiency in state-owned financial institutions, there are still no actions will take to increase their market share, such as to improve service quality and develop new financial products. Secondly, borrowers and lenders' information asymmetry caused the borrowers couldn't know whom the money invest to and how about the benefit.The effectiveness and fairness doesn't play a role in the a incomplete market system. Thirdly, the emerge of Internet Finance greatly eases the lack of individual invest demanding such as limited investing channels and methods especially for the so called "social vulnerable groups", SEM and individuals. Fourthly, domestic websites known as higher customer gathering. So some magnates, such as Tencent, Ali and Baidu,take obvious advantage of website promoting and financial products broadcasting depending on their good reputation and social images. Generally speaking, compared with complete financial market in western countries, Internet Finance in China has developed rapidly rely on the incomplete financial market and system. At the same time, some problems exposed our disadvantages in the development of Internet Fiance especially the lack of regulations and laws which will cause the disorder in control, operating and supervision, put consumers' interest or even safety at risk, disturb the financial order and affect the economic growth and other social issues.

\section{The MAIN InTERnet FinANCIAL Risks ARE FACED}

It is useful to analyze domestic internet finance wholly and deeply, and take actions and regulations to improve the situation now we faced if we could summarize the types, characteristics and hidden problems.

\section{A. Risks of Personal Information Security}

Transaction data is accumulating, and risks of information are increasing especially for internet financial customers. There are no official regulations and laws which conduct responsibility for enterprises for gaining, leaking and using customers' information illegally. It is hard to guarantee the legal rights of private customers. As the data showed, $74.1 \%$ Chinese netizens were bothered with information security problems such as personal information leaking, embezzling account code, harassing text messages and phone fraud.

\section{B. Risks Concerned Law}

China's internet finance has developed rapidly, but also lack of supervision and rules to regulate. Laws existing now have no clarified Legal provisions for internet finance in the permission, supervision, identification, personal information protection and E-contact security. Therefore, both sides of the transaction bear more risk for uncertainty from all sides and finally carried out according to the provisions of the agreement and arbitration.

\section{Risks of funds Safety}

Risk of capital security could be summarized in 3 types. The first is the risk of benefit. Internet financial products attract customers rely on good reputation and higher return on investment of companies which considered as more security and stable. However, the benefit will be reduced if the monetary fund get into trouble. The second one is the risk of liquidity for different terms of Investment and Financing. Generally speaking, the term of investment is a year. The term of lending is usually longer than a year. When the deadline is coming, the risk of monetary liquidity will occurred if the investment is not cashing in time. The third one is credit risk for the incomplete collateral mechanisms. For instance, internet 
Financing Platforms guaranteed for themselves and supervision for reserve capital is irregular. Besides, Certificates of identification and proofs for assessing provided by borrowers are hard to verify.

\section{Risks of Supervision}

Firstly, the process of applying permission is risky. Generally speaking, every company should hold a legal license allowed operating financial business. However, the central bank only issues licenses to the third-party payment companies That means other kinds of internet companies only need to enrolled as financial consulting companies register at the local Industrial and Commercial Bureau. Low standard may cause complexity and disorder. Bad money driving out good money occurred sometimes. Secondly, it is risky in the operating process. Take P2P lending as an example. Lending companies don't publish their operating indicators, state of money entering and leaving, progress of program, settlement and bad debts to public for lacking of supervision. Therefore, investors can't trail their benefits in time. Thirdly, methods to set the defaults. P2P lending usually frozen the line of credit, capital and publish its information on line to punish delinquent customers. Because general financial lending companies are not included into the state credit reference system, companies can't record customers default into credit reference system like commercial banks usually do.

\section{E. Internet Fund Investing and Raising}

The first one is money laundering. Internet Finance's efficiency and concealment incur the diversity, specialization and complication of money laundering methods integrated with traditional and internet. Moreover, some crimes will infringe on consumers' rights and interests and trigger some potential risks such as fraud, illegal fund-raising, hackers breaking.

\section{SUCCESSFUL EXPERIENCES OVERSEAS}

\section{A. Legal Environment}

Aiming at developed legally and standardized, Internet Finance usually has its own laws or be included into the existing law system in developed countries. Since last century, developed countries revise and improve relevant laws and specific provisions to comply with the development of Internet Finance. For example, Laws, like Provisions of Internet and National Bank, Legal Framework of Global E-commerce, Electronic Signature Law and Electronic Fund Transfer Act, firstly passed in US which build a legal framework to supervise Internet Finance. Then US issued some act and regulations to lay a foundation to the well development of Internet Fiance, such as The safety and Sound Review Process of Electronic Banking Service, Digital Privacy Act and Computer Security Act.

\section{B. Market Environment}

Well-developed capital market and external credit rating system create a good environment for the development of Internet Finance overseas. Well-developed capital market makes the monetary sources be trusted, capital allocation and risk share are various. Well-developed credit rating system makes companies can gain the information to assess the risk of customers in short time and lower cost to and improve efficiently.

\section{Supervised Methods}

Usually, analyzing information both obtained via internet and traditional credit system is a new way to increase the verified efficiency, reduce cost, and control risk in foreign countries. Besides, internet companies mainly gain money from management fee and commissions, rather than from price competitiveness. And internet firms overseas pay attention to the concentration, liquidity and advocate invest diversification and in short-term.

\section{Risk Control}

In order to ensure the safety of investors' capital, full information disclosure and risk disclosure are required abroad. For instance, P2P lending was included in the securities regulation and need to complete the the applying process and enroll at U.S. Securities and Exchange Commission. Required materials are: the mode of platform, state of operating, financial situation, potential risks, management team, and compensation system. Besides, P2P companies should submit certification of usufruct and details to U.S. Securities and Exchange Commission and publish to the everyone. The content published will be an essential material if the P2P companies were issued by investors. Next, there is a limited number for investing and financing both as individuals and companies. For example, JOBS, an act passed in April, 2013, required no money could raise over $\$ 1$ million a year via internet platform; money to invest can't over 5\% of your annual income if your income wouldn't reach \$ 100 thousand. But money to invest can reach $10 \%$ if your income over $\$ 100$ thousand each year.

\section{SugGeStions FOR THE DEVELOPMENT OF DOMESTIC INTERNET FINANCE}

\section{A. Accelerate the Process of Internet Finance Law Issuing}

The existing laws related with Internet Finance are Commercial Banking Law, Securities Law and Law of Insurance. However, there are no certain laws to supervise Internet Fiance. It is easy for criminals to take advantage and hard to guarantee the legal rights of customers under the disorder of financial management recently. Therefore, according to domestic internet financial situation, the national legislature should revise relevant laws to build a good environment. Even new laws should be making to clarify the authority-responsibility relationships of internet service, regulate trading behaviors, and provide laws to arbitrate if transaction disputes occurred when time is ripe.

\section{B. Enhance Supervision of Internet Finance}

It will be suitable to establish the Internet Financial Supervisory Commission to enhance supervision on Internet. This commission, participated by the central bank, commercial banks, securities, insurance and other relevant authorities like Ministry of Finance, MIIT and Ministry of Justice, is responsible for the supervision of Internet Fiance, and issuing relevant laws to make sure the authoritative, professionalism, comprehensiveness, and efficiency of supervision. At the same 
time, every department should share information and operate to avoid systematic financial risks.

\section{Improve Internet Finance Risk Prevention}

First of all, strictly check is necessary in the qualification process. All companies, providing Internet Financial service, should apply at the supervision department and submit the application. After strict check and formal approval of supervision department, eligible companies can do business formally. Secondly, establish the information publicity system. Internet financial companies should report their situation about enterprise management, capital adequacy, liquidity, customers' privacy protection, secure transaction system, and electronic transport records to the supervision department in time for publicity and reference. Thirdly, build the third party information security risk assessment to evaluate risk level precisely and warn early for relevant department regulating risk according to different level. Fourthly, financial security system should be established. On hardware speaking, more securities should be involved in to improve the ability of information system preventing hacker and virus. On internet operating speaking, improve the internet website security of portals. On technical support speaking, develop new information technology with original intellectual property rights to avoiding hidden trouble caused by introducing from foreign countries which may threaten domestic financial security.

\section{Establish Internet Finance Credit System}

Internet Finance growth rapidly was mainly relying on well-developed credit assessment system. Recently, internet loans refer to the credit system are based on default. According to the default record, the internet companies decide whether invest or not. But it is still hard to calculate the invest risk. Some suggestions may be useful. Information data accumulating by platforms of internet loans companies can provide to credit bureau if permitted by individuals. The credit bureau and internet loan companies build a shared data system. Therefore, The credit bureau provides service to internet companies and assess the borrowers situation to reduce investing risk with standard management and classified and integrated information.

\section{E. Protect Consumer's Rights and Interests}

Within the rapidly development of internet service, consumers rights and interests are threatened by the process of identification verify and capital supervise. For identification check, it is necessary to clear the responsibilities of digital signature, improve the security of internet accounts and elimination some provisions concerned with E-contract may violate consumer's rights and interests. In order to ensure the safety of large capital, trust fund provided by the third party financial institutions like banking would useful. For the most important capital, funds and internet curtails, it is essential to control the high risk capital rate and concentration. For internet enterprises with more social funds and various source of marketization of globalization and integration. Fourthly, it is in favor of fair competition in financial market. State banks are monopoly enterprises all the time. Their profit and income are higher than other normal companies. In recent years, the situation of these goliaths had changed gradually, and the trend gaining funds, it is vital to build an information disclosure system for customer to check the operating situation and risk management in time. Besides, internet firms should enhance the security management of accounts 'personal privacy. Legal sanction, various form fined to control operate business, will be take once customers' information was leaked. .

\section{PROFOUND IMPACT OF INTERNET FINANCE}

Throughout history, it is easy to find every financial innovation will bring some negative impact in a short period. But after some adjustment and improvements, transactions cost would reduce. In the long term, financial innovation can promote production and economic growth. There is no exception for Internet Finance. In a short term, Internet Finance will suck some funds which supposed to be deposited in commercial banks, decrease the demand of real money and impact the effectiveness of central bank policy. Besides, for its immature, confined management and risk assessment, it is hard to guarantee the personal information security and fund cash to real money. Fraud, money laundering happened usually. In a long term concern, analyzing of profound impact brings to our financial industry summarized as follows:

\section{A. Internet Finance Impact on Traditional Finance}

Some opinions believe, Internet Finance will replace Traditional Finance. Others think Internet Finance is an affiliation to Traditional Finance and would not threaten it which this paper agreed with. A sector of Internet Finance is an affiliation to Traditional Finance, such as the third party payment is a double-win integrated with banking and the third party. In addition, some business will be ignored by traditional financial service, such as individuals and SME lending. P2P lending is a way to supplement. For Traditional Finance, it is necessary to adapt to the change and participate in the financial innovation to avoid crash even though Traditional financial institutions take advantages in public trust and risk supervision.

\section{B. Promote Reform of Financial Marketization}

First of all is Interest rate liberalization. Some money, supposed to be deposited in banks, is distributed to some new internet financial products like Yu'ebao. In order to avoid happening again, banks improve Interest rate to retain customers. Therefore, Financial Service Authority will relax the controlling of interest rate. Secondly, concern with reforms of financial system. Products provided by Internet Finance are required cross-industry cooperation. So integrated internet financial platform need the support of mixed management system. But traditional way of separate business operation is hard to satisfy the demand. So, reformed is necessary. Thirdly, quicken the process of financial globalization and integration. Generally speaking, business below the line will limited by official region. It usually provides service in their jurisdictions. On the contrary, online financial service has no limits in space and time.

\section{Build a Fair and Win-win Financial System}

Some scholars believe the best financial structure is combined with demand from real economy to internet service. The most comparative companies are labor-intensive enterprises especially for SME. And great support is needed for them to develop. Until now, Traditional institutions close 
their door to SME and individuals who got a lower income for higher open cost, labor cost and operating fee. However, this situation generated Internet Finance. Internet Finance, takes advantage of low cost, provides financial service, loans, microfinancing, and payment and settlement to SME and individuals. It fills in the blanks of existing financial service and contributes to build a fair, free and efficient financial environment.

\section{Accelerate Reform of Financial Supervision}

Firstly, the biggest difference of Internet Finance and Traditional Finance is Internet Finance highly relying on internet system. Therefore, the safety and stabilization of internet is the most important part to supervise Internet Finance. It broadens the scale of financial supervision. Secondly, Traditional Finance usually provides service to large and medium-sized enterprises. On the contrary, Internet Finance provided service to SEM and individuals. Therefore, within the growth of Internet Finance, protection consumers' rights and interests will be a virtual part of financial supervision. Secondly, the most risky internet financial service is P2P lending. There are two reasons to explain this situation: It is difficult to set a guarantee system by using mortgage for $\mathrm{P} 2 \mathrm{P}$ lending. So the loan contract is limited for borrowers to follow and more risky. Besides, P2P lending occurred in virtual space is highly incurring information asymmetry and adverse selection. Therefore, establishing an appropriate credit management system and sharing information will be a new mission to supervise the domestic Internet Finance development.

\section{DEVELOPMENT TRENDS OF INTERNET FINANCE}

There are plenty of risks and obstacles now we faced when Internet Finance grows fast. So how to solve these obstacles is more crucial. How about the development trend of this new financial service in the future? This paper will explain as an integration for the following reasons:

\section{A. The Integration of Internet and Financial Industry}

Internet is the most important applying tool to be used in various sectors and thousands of households. Many business have finished its close integration with internet. The most successful integration of traditional retail industry and internet is the popularity of online shopping. Thus, the integration of Traditional Finance and internet is bound to happen now and future. Internet Finance and Traditional Finance could be integrative, complementary, win-win and mutual benefit from Internet derivatives business.

\section{B. Finance Integrate into Other Industries Comprehensively}

The existing financial boundaries will vanish when the integration of internet financial enterprises and traditional financial enterprises happened. Finance will integrate into other industries via ubiquitous internet and the relationship of finance and other industries will be redefined. future society stress on timeliness. Therefore integrated financial industry will be the key point to support the efficient operation of the whole society. And internet will be the mainly implementation for financial industry to bear its social function.

\section{REFERENCES}

[1] J. Wang, "Analysis on the Form of Internet Finance and Its Impact on Commercial Banking from the Perspective of Financial Functions," Finance \& Economics, pp. 57-57, March 2015.

[2] C.H. Ren and J. Lu, "Internet Financial Risk and Governance," Academic Communication, pp. 106-111, November 2014.

[3] Y.F. Lin, X.F. Sun and Y. Jiang, "The Optimal Economic Structure Theory in the Development of Economy," Economic Research, pp. 3136, August 2009.

[4] Z.M. Ming, "Some Problems about the Current Internet Financial Risks," Commercial Bank, December 2013.

[5] "The People's Bank of China Financial Stability Analysis Group," China's Financial Stability Report, Beijing, China's Financial Press, 2014.

[6] J. Wang, "Financial Formation, The Internet:Consumer behaviour change and Bank Revolution," pp. 23-23, September 2014.

[7] S.Y. Xiang, "The Present Situation and Development Trend of Research of Internet Financial Forms," May 2014.

[8] N. Wang, H.J. Wang and L.C. Zhao, "The Concept of the Internet Financial Foundation and the Differentiation Model," South Finance, pp 37-42, June 2014.

[9] F.Q. Cao, "Development and Challenge of Internet Finance," China Marketing, July 2014

[10] W. Jing, "Based on the Perspective of Financial Function of the Internet Financial Form and the Impact on the Commercial Banks," Finance BBS, pp. 56-64, March 2015. 